\title{
Halicephalobus gingivalis (H.deletrix) in the brain of a horse
}

\author{
Halicephalobus gingivalis (H.deletrix) no cérebro de um eqüino \\ Rosemeri de Oliveira Vasconcelos ${ }^{\mathrm{I} *}$ Karen Regina Lemos ${ }^{\mathrm{II}}$ \\ Julieta Rodini Engracia de Moraes ${ }^{I}$ \\ Vívian Palmeira Borges ${ }^{\text {III }}$
}

\section{- NOTE -}

\section{ABSTRACT}

A 10-year-old Mangalarga gelding with rhabditiform nematode infection in the brain is described. Clinical signs were limited to circling and right side paralysis. Histological examination of the brain revealed marked gliosis and discreet edema. The perivascular mononuclear inflammatory infiltrate was composed of few layers of lymphocytes, plasmocytes and macrophages and rare eosinophils. The presence of rhabditiform nematodes was associated with the infiltrate. Areas of malacia associated with the parasites and parasite tracks with axonal spheroids were also seen close to the vessels and to the etiological agent and were more evident in the white matter. In the meninges there was moderate inflammatory infiltrate associated with perivascular parasites. The identification of the nematode was based on the histological examination of the cerebral fragments.

Key words: nematode, equine, central nervous system, Micronema deletrix.

\section{RESUMO}

Um eqüino macho, com 10 anos, Mangalarga, apresentou uma infecção por um nematódeo rabditiforme no cérebro. Os sinais clínicos limitaram-se ao fato de o animal andar em círculos e apresentar paralisia do lado direito. $O$ exame histológico do cérebro revelou acentuada gliose e discreto edema intersticial. $O$ infiltrado inflamatório mononuclear perivascular era composto por poucas camadas de linfócitos, plasmócitos, macrófagos e raros eosinófilos, associados aos nematódeos rabditiformes. Áreas de malácia e trajetos com esferóides axonais são vistos ao redor de vasos e do agente etiológico, sendo mais evidentes na substância branca. Nas meninges, o infiltrado inflamatório foi moderado e associado a parasitas perivasculares. A identificação do nematódeo foi baseada no exame histológico do cérebro do cavalo.

Palavras-chave: nematódeo, eqüino, sistema nervoso central, Micronema deletrix.

The migration of larvae of insects and of nematodes may affect the CNS of several species of domestic animals. The parasites reported in equines include: Micronema deletrix, Hypoderma lineatum, Hypoderma bovis, Strongylus vulgaris, Draschia megastoma, Setaria sp. and hydatid cysts of Echinococcus granulosus (GEORGE, 1990). The genus Halicephalobus, previously known as Micronema, is classified in the order Rhabditida, which includes freeliving nematodes found in the soil and decaying organic matter. Only parasitic females, larvae, and eggs have been described in tissues, another habitat in which males and females exist is suspected, although not yet described (RAMES et al., 1995). The infections in horses and humans have been assigned to $\boldsymbol{H}$. deletrix. It is believed that the species reported in horses and humans is $\boldsymbol{H}$. gingivalis and that $\boldsymbol{H}$. deletrix is its synonym (ANDERSON et al., 1998). ISAZA et al. (2000) have the first report of this parasite in a zebra (Equus grevyi).

\footnotetext{
IDepartamento de Patologia Veterinária, Universidade Estadual Paulista (UNESP), Faculdade de Ciências Agrárias e Veterinárias (FCAV). Via de Acesso Prof. Paulo Donato Castellane, s/n, 14884-900, Jaboticabal, SP, Brasil. E-mail: rosevasc@fcav.unesp.br.* Autor para correspondência.

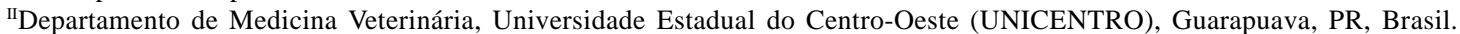

IIIUniversidade Católica Dom Bosco (UCDB), Campo Grande, MS, Brasil.
} 
HUBBARD et al. (1985); SPALDING et al. (1990); SIMPSON (1993) and RUGGLES et al. (1993) described the organism by reconstructions from various planes of sections, as being 250 to $370 \mu \mathrm{m}$ long, 15 to $20 \mu \mathrm{m}$ in diameter, with a cylindrical body, with a rhabditiform esophagus and the mouth was cylindrical ( $5 \mu \mathrm{m}$ deep and $2 \mu \mathrm{m}$ in diameter).

The method of infection is unclear but it is presumed to be contamination of oral or nasal wounds, based on the common infestation of these sites. It is presumed that the nematodes enter the tissues through lesions and are carried to other parts of the body in blood and lymph (RUBIN, 1974; KEG et al., 1984; GEORGE, 1990; RAMES et al., 1995) or through the optic nerve - optic tract and that the contamination of ocular wounds would be the entrance (RAMES et al., 1995).

Halicephalobus deletrix should be considered a facultative parasite in horses and humans. The brain is the most commonly involved site, followed in descending order by the kidneys, oral and nasal cavities, lymph nodes, spinal cord and adrenal glands. Infections involving the heart, stomach, liver, ganglion and bone have also been reported (JOHNSON \& JOHNSON, 1966; SPALDING et al., 1990; KREUDER et al., 1996). Massive intracranial invasion in horses is acute and of short duration (BLUNDEN et al., 1987; JUBB \& HUXTABLE, 1993). However, ALSTAD et al. (1979) observed parasitism in a horse with a 4-week history of clinical signs referable to the urinary tract and central nervous system.

RUGGLES et al. (1993) suggested that some (or all) of paresis observed may be a consequence of hypersensitivity or toxic reaction to dying parasites following treatment. Brain infection, ataxia, incoordination and paresis were the typical course even when the coordinated treatment was not given.

The predominant inflammatory cells are plasmocytes and lymphocytes, occasional eosinophils and numerous macrophages, giant cells and epithelioid cells (RAMES et al., 1995). Similar inflammation was observed, in systemic infestations, in the kidneys (FERRIS et al., 1972; RUBIN, 1974; POWERS \& BENZ, 1977; RAMES et al., 1995; ISAZA et al., 2000; KINDE et al., 2000), lymph nodes, uterus and heart (ISAZA et al., 2000), testicles (KINDE et al., 2000), stomach, lungs, joints, adrenal gland (SIMPSON et al., 1988), prepuce (DUN et al., 1993), bones (SIMPSON et al., 1988, KREUDER et al., 1996; TEIFKE et al., 1998) and the spinal cord, the roots of the peripheral nerves and the cauda equina (JOHNSON et al., 2001). The predominant localization of the rhabditiform larvae is perivascular. Many of these nematodes were seen in the tunica adventitia and occasionally in the tunica media of the arteries (FERRIS et al., 1972; RUBIN, 1974; GEORGE, 1990). Many authors report the presence of larvae, adult worms and eggs in the granulomatous lesions of $\boldsymbol{H}$. gingivalis. This fact would be a criterion to differentiate from Strongyloides sp., as besides the different morphology, eggs and adult parasites are not seen in the cutaneous lesions of the horse (DUNN et al., 1993).

In September 2001, a 10-year-old Mangalarga gelding with sudden onset of neurological signs, was seen by a self-employed veterinarian in the city of Sertãozinho, São Paulo State, Brazil. Clinical signs were limited to circling and right side paralysis, which progressed rapidly to lateral recumbency. The horse was euthanized four days after the onset of clinical signs.

Unfortunately only a small portion of the cerebral cortex was sent to the Department of Veterinary Pathology of UNESP - São Paulo State University, in Jaboticabal, SP, Brazil. Histological examination of sections from cerebral cortex revealed diffuse and marked gliosis in the neuropil and discrete interstitial edema. In some areas satellitosis and neuronophagia were observed. Different stages of neuronal degeneration were observed and they were characterized by neuronal bodies in the phase of peripheral chromatolysis or already in necrotic state. There was a discrete mononuclear inflammatory infiltrate with lymphocytes, plasmocytes, macrophages and rare eosinophils. The presence of specimens of nematodes was verified associated to the infiltrate, in longitudinal and transversal sections (Figure 1A), besides areas of malacia near the parasites (Figure 1B) and areas rich in gitter cells. Tracks with axonal spheroids were also observed near the blood vessels (Figure 1A). In the meninges moderate lymphoplasmacytic infiltrate associated to extravascular parasites was verified. The identification of the nematode was confirmed by the examination of the histological material from the horse, mainly because of the rhabditiform esophagus of the parasite. The parasite body is cylindrical and is $200 \mu \mathrm{m}$ long and 15 to $20 \mu \mathrm{m}$ in diameter. The histopathological description of this case report is similar to the literature descriptions of granulomatous inflammation associated with nematodes in the CNS of animals (FERRIS et al., 1972; RUBIN, 1974; POWERS \& BENZ, 1977; BLUNDEN et al, 1987; GEORGE, 1990; JOHNSON et al., 2001).

The $\boldsymbol{H}$. deletrix infection appears to have a low incidence in Brazil, as there are no descriptions in the literature. However the clinical observations and field pathological investigations are few. Thus we have to consider the differential diagnosis with this parasite for horses with neurological signs. 

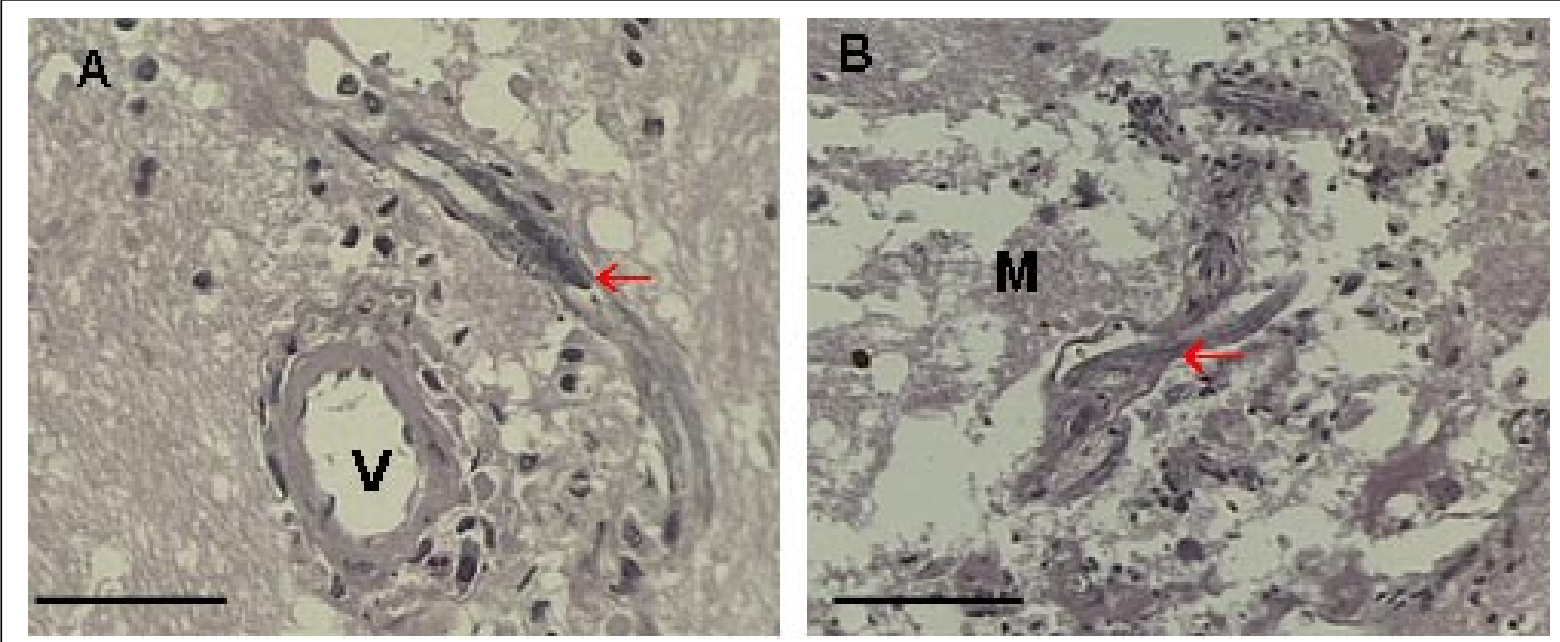

Figure 1 - Photomicrograph of the cerebral cortex of an equine, with Halicephalobus gingivalis nematode (red arrow). (A)Around a blood vessel (V). (B) Parasite arrow associated to areas of malacia (M). Hematoxylin and Eosin. (Bar $=25 \mu \mathrm{m})$.

\section{REFERENCES}

ALSTAD A.D. et al. Disseminated Micronema deletrix infection in the horse. J Am Vet Med Assoc, v.174, p.264-266, 1979

ANDERSON R.C. et al. Halicephalobus gingivalis (Stefanski, 1954) from a fatal infection in a horse in Ontario, Canada with comments on the validity of $\boldsymbol{H}$. deletrix and a review of the genus. Parasite, v.5, n.3, p.255-261, 1998

BLUNDEN A.S. et al. Halicephalobus deletrix infection in a horse. Equine Vet J, v.19, n.3, p.255-260, 1987.

DUNN D.G. et al. Nodular granulomatous posthitis caused by Halicephalobus (syn. Micronema) sp. in a horse. Vet Pathol, v.30, p.207-208, 1993.

FERRIS D.H. et al. Micronema deletrix in equine brain. Am J Vet Res, v.33, n.1, p.33-38, 1972.

GEORGE L.W. Diseases of the nervous system. In: SMITH B.P. Large animal internal medicine. St. Louis: Mosby, 1990. p.901-1045.

HUBBARD R.M. et al. Micronema granuloma in the gingival of a horse. J Am Vet Med Assoc, v.187, n.5, p.505-507, 1985

ISAZA R. et al. Halicephalobus gingivalis (nematoda) infection in a Grevy's zebra (Equus grevyi). J Zoo Wild Med, v.31, n.1, p.77-81, 2000.

JOHNSON J.S. et al. Radiculomeningomyelitis due to Halicephalobus gingivalis in a horse. Vet Pathol, v.38, n.5, p.559-561, 2001.

JOHNSON K.H.; JOHNSON D.W. Granulomas associated with Micronema deletrix in the maxillae of a horse. J Am Vet Med Assoc, v.149, n.2, p.155-159, 1966.
JUBB K.V.F.; HUXTABLE C.R. The nervous system. In: JUBB K.V.F. et al. Pathology of domestic animals. 4.ed. San Diego: Academic, 1993. V.1, p.267-439.

KEG P.R. et al. Micronema deletrix infection in a Shetland pony stallion. Equine Vet J, v.16, n.95, p.471-475, 1984

KINDE H. et al. Halicephalobus gingivalis (H. deletrix) infection in two horses in southern california. J Vet Diagn Invest, v.12, n.2, p.162-165, 2000.

KREUDER C. et al. What is your diagnosis? J Am Vet Med Assoc, v.209, n.6, p.1070-1071, 1996.

POWERS R.D.; BENZ G.W. Micronema deletrix in the central nervous system of a horse. J Am Vet Med Assoc, v.170, n.2, p.175-177, 1977.

RAMES D.S. et al. Ocular Halicephalobus (syn. Micronema) deletrix in a horse. Vet Pathol, v.32, n.5, p.540-542, 1995.

RUBIN H.L. Equine infection with Micronema deletrix. J Am Vet Med Assoc, v.165, n.3, p.256-258, 1974.

RUGGLES A.J. et al. Disseminated Halicephalobus deletrix infection in a horse. J Am Vet Med Assoc, v.203, n.4, p.550 552, 1993.

SIMPSON R.M. Diagnosis and treatment of Halicephalobus (syn micronema) deletrix infection. J Am Vet Med Assoc, v.203, n.10, p.1385-1386, 1993.

SIMPSON R.M. et al. Micronema deletrix - induced granulomatous osteoarthritis in a lame horse. J Comp Pathol, v. 99, n.3, p.347-51, 1988.

SPALDING M.G. et al. Halicephalobus (Micronema) deletrix infection in two half-sibling foals. J Am Vet Med Assoc, v.196, n.7, p.1127-1129, 1990.

TEIFKE J.P. et al. [Halicephalobus (syn. Micronema) deletrix as a cause of granulomatous gingivitis and osteomyelitis in a horse]. Tierarztl Prax Ausg G Grosstiere Nutztiere, v.26, n.3, p.157-161, 1998.

Ciência Rural, v.37, n.4, jul-ago, 2007. 